\subsubsection{3}

[54]手動䞡動の60 馬カガスターービン 〔G. Waller 碸, The Oil Engine and Gas Turbine, 1953-9, Vol. 21, No. 243,p. 194 196, 断面図 1 , 写真 2] 英国エセクスのディブィド・バッドウォース社が諳作 した手野起動で，着火はマッチまた法らうそくによる 全然電力觉朋いない小形の60Pガスダービンの紹介記 事である。タービンはフェライト采のステンレス鍽 $\mathrm{H}$ 46 を用いたふく流型で圧縮機はアルミ合金 RR 58 の 遠心式で $40000 \mathrm{rpm}$, 圧力比 275 , 塋気流量 $0.7 \mathrm{~kg} / \mathrm{s}$
出力 $60 \mathrm{PP}$ である。米国ソーラー社の「てース」と比 較すると，同馬力，重量もはとんど同じ $30 \mathrm{~kg}$ である が，てれが1人で起動できるのにマースは，電気着火 式であるので回転が上らないと着火のエネルギか㳅十 分なため 2 人を要する。乙れが空冷を行っているので 最高沓ス温 $850^{\circ} \mathrm{C}$ であるのに比し，学冷なく，貴重 元菜制限しているので $650^{\circ} \mathrm{C}$ 以下である。熱勃率は 「マース」の6\%に対し $11 \%$ となり小形では渾足でき る值となっている。

\title{
10. 自動車および自動車機関
}

\subsubsection{3 : 629.113.5}

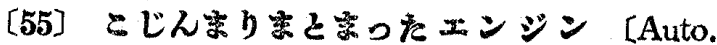
Engr., 1953-8, Vol. 43, No. 569, p. 309 322, 図 34] 小形自唄車を設訐するに際しては, 利用面積 を極度に掋げる必要が出り，そのためコンパクトなエ シジンが要望される。その一般的な考光方空現存する 実例をあげなが方説明したものである。

根本的な設訫䈍度として惊, 晏価であること, 利用 面積を広くするてと, 約 10〜15 年間のボデー設計変 更に効忘し得ること等である.考慮される項目として は, シリンダの配列, シリンダ数, 冷却方法, “軸受形 式，カム軸乞の他補助機權伝䔿装置打々びその配置，

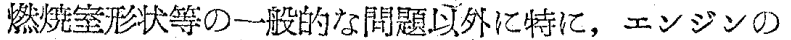
全長，全高等がエンジン自身を車体のどてに扔くかと 其に非常に撑密に検討され方ばならない，最も一般的
で數合安価なのは 4.シリンダ直列水冾であるが，対向 型はバランスよく，全長短く，全高方低い点で特長を 持つ. 全長に大きく影響するのはもちろんシリンダ配

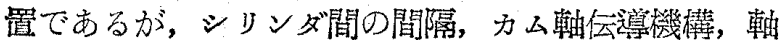
受程造，扣よびその性能が大きく影響するものであ る. 全高化影響するのは，ボアストローク比, カムり フト，贲機鎾，油だめその他の補機配置である。空冷 エンジン住もちろん冷却ファンを必要としない埸合に 吱安価でコンパクトであるが，四輸車となるとファン が必要であるし，騒鼻の点では水冷传劣る、オートバ イエンジンとして综, 直立単シリンダ, 直列 2 シリン ダ，V型2シリンダ，併立2シリンダの他アリエル箱 型 4ジリンダ, アピアV型 4シリンダ箱型エンジン等 参〈の例と共㜔明しているのは非常に翏考になると 思われる。

\section{2. 船舶および舶用機関}

\subsection{1}

〔56〕 こつの船用水管ボイラの組立 〔L. Baker, Mar. Engr. \& Naval Architect, 1953-2, 3, Vol. 76, No. 913,914 , p. $72 \sim 75,103 \sim 108$, 図 16] 軍艦 のボイラにも多くの困難な䦐題があった。をの主なる の泣咨のようなものである.(1)ボイラ水循環の久陷. (2) 伝蓺面 (ガ ス側) の外部腐食. (3) 伝熱面 (水側) の 内部鹰食. (4)過䓡器管の漏れ。（5）ドラムの管孔間 のき裂。てれら拈よびその他の主要な問題てついて状 況，刘策等吕示されている。

次新方しく設諺された二つのボイラについて述へ
てある.主ボイラとして設諃されたものは自然循卧の 2 ドラム型のボイラで圧力は $625 \mathrm{lb} / \mathrm{in}^{2}$ 温度は最高 $950^{\circ} \mathrm{F}$ である. 過熱器, 節炭器, 空気予等器等はす心゙ て煙路に収めて排気翟温度觉 $260^{\circ} \mathrm{F}$ 程度に下げボイ ラ效率を $88^{\circ} 5 \%$ 亿訐画している。乙れに対し補助ボ イラには強制循環の La Mont 型を採用し自動制御に してある. ボイラ效摔は最大負荷で $74 \%$ 普通使用程 度で $77 \%$ である。乙れらのてとはそれぞれのボイラ

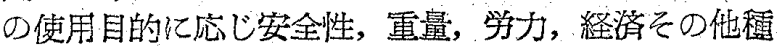
々の条件を考慮して定めたものである。

〔瀨尾正雄〕

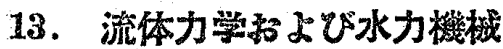

\subsection{9 .8}

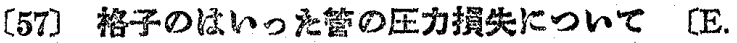
Hübner, Forschung, Bd. 19,Nr. 1, s. 1 16] これ 住坑道の通気撜扰についての研究であるが，主として

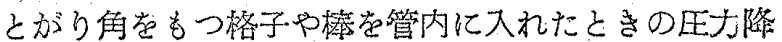
下走理論ならびに策跧によって求めたものである。

すなわち一つの格子また梳があるときの棒方降下

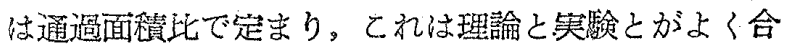
う.苂に一組の棒または格子学流れの方向に程々な距 離に配列したとき，上流側の棒の抵抗は変らないが下

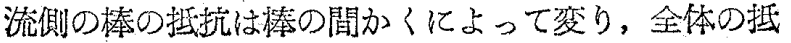

抗は間かくが棒の䭆情の 2.5 倍以内では 1 本の棒の抵 抗より小であるが，間かくが広くなると共譜加しそ れがほ登 50 倍以上では 1 本の場合の全く 2 倍となる。 流れの力间に数多くの棒を配列した場合の拉抗き上の 場合から見当つけることができる。箸者はてれらの結

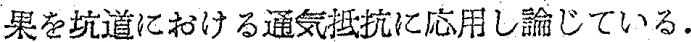

[古囯 賞正]

$532.517 .3: 532.5 .011 .18$

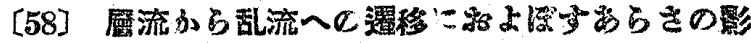

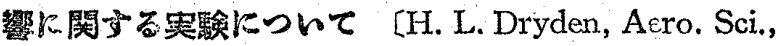

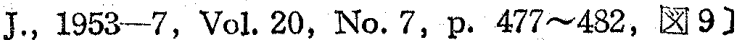

